\title{
Preparing for Quality EFL Teachers: The Disjuncture Between Policies and Practice in The Internet Communication Technology (ICT) Use in Classroom Context
}

\author{
Koesoemo Ratih1, Harun Joko Prayitno2, Anam Sutopo3, Laurence Tamatea4, Muhammad Syahriandi \\ Adhantoro5 \\ (kr263@ums.ac.id ${ }^{1}$, harun.prayitno@ums.ac.id², anam.sutopo@ums.ac.id ${ }^{3}$, \\ laurence.tamatea@cdu.edu.au ${ }^{4}$, m.syahriandi@ums.ac.id $\left.{ }^{5}\right)$ \\ 1,2,3,5 Universitas Muhammadiyah Surakarta, Surakarta, Indonesia \\ ${ }^{4}$ Charles Darwin University, Australia
}

\begin{abstract}
Globalization has resulted in great consequences on mobility, competition and employability. It certainly implies high expectation and demands on quality and graduate standards for employability. Pre service teacher institutions need to reform several aspects to meet the demand of this globalised world. One significant aspect of reform in EFL and more broadly is the role of technology and how globalisation presents new challenges and tasks for teachers because technology has changed the tradition of English teaching significantly. In addition, various technological alternatives have the potential to make teaching more interesting, to widen students' knowledge about the culture of English, to create more conducive environments and to improve teaching efficiency. Many recent studies suggest that producing quality graduates of EFL Teacher Education is challenging. Also, global agencies and policies have documented the insufficient competence of graduates of English Teacher Education institutions even though some recommendations for developing quality EFL teachers have been promoted. This paper aims at disseminating the result of a Carspecken critical ethnography study focusing on the issues and inconsistency between policy and practice on the implementation of ICT in the classroom which constitutes some challenges in preparing globally competitive EFL teacher graduates in Central Java, Indonesia. Globalization theory by Appadurai is applied to explain the presence of the disjunctures between policies and practices. Following Appadurai this study argues a strong degree of disjuncture between education policies and practice in terms of ICT use. What is desired in the global, national and local institutional policies are not always implemented optimally in classroom. Policy makers need to consider this mismatch as a concern in producing quality EFL teachers. The presence of the issues on the pedagogical dimension indicates the lack of awareness of the global message by local institutions. Therefore, this paper provides meaningful insights towards the discussion of the formation of quality EFL teachers not only locally and nationally but also in the broader context of teacher preparation globally.
\end{abstract}

Keywords: disjuncture, critical ethnography, globalisation, classroom context. 


\section{Introduction}

Global organizations, national governments and education institutions have focused their agendas on improving the quality of education systems. Quality of education plays a crucial role in determining a nation's competitiveness [1]. They assert that in preparing for global competition, Indonesian governments have strived to promote strategies to enhance the quality of education. The enhancement of quality education is underpinned by a view that better quality systems will produce highly competitive human resources to meet the needs of global economic competition.

The 2014 Education for all (EFA) global monitoring report mandates that quality education relies on the most appropriate training for teachers and prospective teachers. It is recommended that initial teacher education is required to prepare teachers to help students from various backgrounds and needs. Teacher education institutions are actively involved in the process of change. This implicitly means that institutions and policies play an important role in the formation of EFL professional teachers. In the interest of extending understanding of the role of policies in the formation of quality EFL teachers, this study investigates the formation of quality EFL teachers through policy documents and how they are responded to in practice focusing on the ICT implementation.

In regards to the policy implementation, there were discrepancies in the messages stated in the policies in the various levels. The focus of this study is on the formation of quality EFL teachers and the implications for quality EFL teacher education programs. Specifically, this paper identifies the differences and the disjuncture between policy and interview discussions which emerged in the data. It reflects on the challenges in constructing a coherent framing of quality EFL teachers.

Teaching practice conducted at schools in which the period of time is in simulated or actual settings is an important time for prospective teachers as they negotiate system reform [2], curriculum reform [3] and challenges to their personal identity [4]. The flow on effects of technology is an issue the student teachers must navigate during this time. One significant aspect of reform in EFL and more broadly is the role of technology and how globalisation presents new challenges and tasks for teachers because technology has changed the tradition of English teaching significantly. In addition, various technological alternatives have the potential to make teaching more interesting, to widen students' knowledge about the culture of English, to create more conducive environments and to improve teaching efficiency [5], [6]. For example, there are advantages in using multimedia technology in teaching and learning communication skills, such as to improve students' motivation, teaching effects, students' understanding of western culture, teacher-student interaction, supporting contextual learning, promoting students' communication capacity and facilitating malleable adjustment to the teaching material.

Technology-based curriculum and technological practice cannot be separated in the process of promoting effective integration of technology into the pre-service teacher education curriculum [7]. A study by Merç indicates the need for better integration of technology in EFL teacher training and a stronger link between the placement schools and the university [8]. Hismanoglu's study of the prospective EFL teachers' perception of Information and Communication Technologies (ICT) integration shows that those having negative attitudes to ICT integration feel inadequate to use ICT due to insufficient knowledge of ICT. The results of the study imply that training in ICT is critical for pre-service EFL teachers and EFL teachers.

Besides that, a study by Black and Goebel shows the importance of teaching language variety in the Indonesian context using ICT as a teaching media [9]. It is argued that teachers, native or otherwise, cannot genuinely be adequate role models of the sort of dialectal variety 
with which learners of major languages often need to be able to cope. It would surely be even more difficult for them to illustrate the social significance of code choice in such multilingual situations as Indonesia. What is more, models of dialect variety and code choice can be supplied through audio-visual material, such as television programs.

The value of resource materials can be enhanced through computerised access and manipulation; even authentic multimedia material can achieve better results than the individual teacher. Motschnig-Pitrik and Holzinger's study also advises the use of ICT to facilitate learning by a combination of student-centred teaching and e-learning [10]. Their case study revealed that such learning demands qualifications and social skills that are very different from those needed for conventional teaching. Interestingly, it appears that new media could be extremely well employed to support a coach or facilitator in numerous ways particularly relevant to a studentcentred approach.

To summarise, the role of technology and how globalisation presents new challenges and tasks for teachers are significant aspects in reforming the tradition of English teaching. Mandated ideas existent in the global policy agenda cannot be ignored in this globalised world. The role of technology to facilitate learning is important. It eases the process of delivery to the students. In accordance with Misra and Koehler's conceptual framework for educational technology, by building on Shulman's formulation of 'pedagogical content knowledge', it is important to integrate technology with pedagogy [10]. Therefore, in this study of preparing quality EFL teachers in Indonesia, integrating technology in pedagogical content knowledge is vital in this global era. The following section discusses the Appadurai's globalisation theory focusing on techno-scape and ideo-scape which are applied in the selected methodology [12], [21].

\section{Method}

This Among the influential proponents of globalisation is Arjun Appadurai. He argues that globalisation does not bring homogenisation of culture. Globalisation does not produce a single universalising global space, but spaces that are disjunct. He names these spaces as cultural flows. Appadurai saw globalisation as a fluid and dynamic phenomenon tied to worldwide migrations (both voluntary and involuntary) and the dissemination of images and texts via electronic media [11].

According to Appadurai, the new global cultural economy is complex, overlapping, and disjunctive [12]. Appadurai classified the cultural flows as five different 'scapes', namely ethnoscapes, media-scapes, techno-scapes, finance-scapes and ideo-scapes [12]. He assured that the five scapes emerge but are not causally ordered (Heyman \& Campbell, 2009). They emerge in and through growing disjunctures. People, machinery, money, images, and ideas now follow increasingly non isomorphic paths; of course, at all periods in human history, there have been some disjuncture in the flows of these things, but the sheer speed, scale, and volume of each of these flows are now so great that the disjuncture have become central to the politics of global culture [12]. Appadurai extended his argument for disjuncture to explain the 'non-isomorphism' of the five global flows. The disjunctures are critical as they manifest through the concept of deterritorialisation. The idea of 'disjuncture' above is adopted to explain the emerging ideas among the flows that in this study are present in the global, national and institutional policy texts and the experience of teaching practice reflected by EFL pre-service teachers. 
The five 'scapes' provide a way of understanding and rendering more visible flows over time. Ethno-scape refers to the view of people who undergo the changing world, for example tourists, immigrants, refugees, exiles, quest workers and other moving groups. These individuals are important features of the world and turn out to have influence within and between nations. Technoscapes refer to the global forms of technology, for example, the use of particular software that can be used by people around the world. This techno-scape intensifies the compression of space and time, as Giddens articulated. Ideo-scapes refer to images that deal with state ideologies, politics, and movements which counter ideologies that capture state power or a piece of it. The elements of ideo-scapes cover the enlightenment worldview consisting of chains of ideas, terms and images, including freedom, welfare, rights, sovereignty, representation and democracy.

Finance-scapes refer to the movement of global capital that flows rapidly: currency markets, national stock exchanges and commodity speculations. Media-scapes refer both to the distribution of the electronic capabilities to produce and disseminate information (newspapers, magazines, television stations, and film-production studios), which are now available to a growing number of private and public interests throughout the world, and to the images of the world created by these media. These Images involve many complicated inflections, depending on

their mode (documentary or entertainment), their hardware (electronic or pre-electronic), their audiences (local, national, or transnational), and the interests of those who own and control them.

Globalisation is not a single process but multiple processes in different sectors or domains of practice [12]. In this study, the writer focuses two scapes, namely ideo-scape and technoscape out of the five 'scapes' - ethno-scape, finance-scape, ideo-scape, techno-scape and mediascape - assist in investigating the flow of cultural material across boundaries. The two scapes help to illustrate how globalisation is articulated in both the experience of teaching practice of EFL pre-service teachers and the policies that set up their experiences in relation to ICT implementation.

\section{Approach}

This paper is part of a research project that explored the formation of quality EFL teachers through the current ideas in global, national and local institutional policy texts and practice. To understand claims about what comprises quality in these various texts, Carspecken's critical ethnography informed the data collection and analysis strategies used in the research project and thereby informed the research presented in this paper [13].

The applicability of Carspecken's critical ethnographic approach is grounded in the identification of a dialectic process [13], [14] that led to the development of a research question to investigate the notion of quality in EFL teaching in educational policy texts in two universities in Surakarta, Indonesia. These institutions were selected on the following grounds. Aside from relatively easy access to both institutions called by the pseudonyms Full Moon University and Sun University, both universities have large teacher-training faculties in Surakarta. Each of them has an English department within which pre-service EFL teachers are trained and together both sites share a cohort of students bounded by commonalities including location (in Surakarta, Indonesia), languages (Bahasa Indonesia and Bahasa Jawa), religion (predominantly Islam), faculty structure (Teacher Training) and English Department. 
The research commenced by collecting documents relating to different levels of policies. For this paper, significant documents at the national level included (state) Law No. 20/2003 pertaining to the National Education System, Government Regulation No. 19/2005 pertaining to the National Standards of Education, and Law No. 14/2005 pertaining to Teachers and Lecturers. At the local (institutional) level, the curricula of the English departments and their microteaching and field-based teaching guides were all identified as significant documents.

Following Carspecken's model, the researchers began by developing research questions as a preliminary step [13]. Generating flexible research questions that could be remodified as the research progressed. This was complemented by interviewing EFL pre-service teachers in Indonesia with regard to their learning and practicum experience which accords with Carspecken's dialogical data generation stage [13] and allows the construction of a preliminary analysis of the interviews to articulate prominent themes. This was followed by an examination of the relationship among the various data sources, which Carspecken addresses in describing system relations [13]. This commenced a significant phase in the criticality of this research projects methodology. In addition, the researcher applied Appadurai's discussion of globalisation, in particular his notion of global [12], to inform the identification if not construction of the system relations across the data sources, especially policy documents used in this study.

\section{Result and Discussion}

In regard to pursuing its goals, The Dakar Framework suggests ICT is important in distributing knowledge and facilitating effective learning and educational development. This implies that in establishing quality teachers, it is important to integrate ICT in the learning process. ICT use must be feasible; therefore it is advised that it be provided at a reasonable price and in practical ways.

(1) Information and communication technologies (ICTs) must be harnessed to support EFA goals at an affordable cost. To be effective, especially in developing countries, ICTs should be combined with more traditional technologies such as books and radios, and be more extensively applied to the training of teachers (UNESCO, 2000, p. 21).

The above quote from the EFA agenda emphasises the importance of applying technology to support the delivery of education, learning and teaching. More specifically, the potential capacity of technology facilitates the spread of information, therefore making it largely essential to integrate ICT in teacher training in an effective way. Despite the often high costs of ICT implementation, there is a strong need, as signalled above, to actualise the use of ICT to meet education goals aligned with Indonesia's economic and education policies. But in this, there emerges a potential disjuncture between the necessity for the use of ICT and the cost of ICT, which can be conceptualised as a disjuncture between ideas flowing along the techno-scape and the realities of financial flows along the finance-scape, particularly in the context of 'developing' countries such as Indonesia.

Madya contends that the acceleration of development in Indonesia should be supported by technology [14]. Madya assures us that technology will certainly facilitate development in remote areas. However, she also acknowledges that limited financial capacity has made it impossible to achieve equity of educational access [15]. The lack of financial resources is a recurring issue, as is the extent to which global policy around the use of ICT for education can accordingly be thwarted at the national and local levels. For example, the schools where the preservice teachers practiced their teaching were not always equipped with a sufficient ICT 
infrastructure. The consequence of this is that the capacity of pre-service teachers to use ICT for learning and teaching varies depending on the school in which they undertake their practice teaching. Some schools are labelled by the pre-service teachers as a 'favourite' school, particularly so in the urban city context where schools are generally well equipped with ICT resources, so pre-service teachers could apply ICT in their teaching practice. In addition, they could adopt technology to avoid monotonous teaching methods and to build students' interest. In this respect, their teacher training had equipped them to meet the expectations of both the National Law [16] and accompanying global messages in so far as the use of ICT to support learning and teaching goes [16], [17]. [18], [19]. At the national level, Government Regulation No. 32/2013 on national education standards promoted the use of technology to support student learning [17]. In line with this national regulation, institutional policies in the form of the FBE guides of Full Moon University require pre-service teachers to be quality teachers who are able to compete through standardisation and competency examinations and to adjust to changes in educational knowledge, technology and society. The guides therefore promote the training of quality teachers by promoting the use of technologies to achieve that goal.

Aside from the reasonably well-equipped urban schools, many schools where pre-service EFL teachers undertake their practice teaching were not well resourced in terms of ICT. It could be argued that such less well equipped schools contradict the requirement for using ICT in education mandated in global and national policy texts. In these less well equipped schools, preservice teachers arguably could not easily reach the standards for the use of ICT for learning and teaching identified in policy. In such schools even an internet connection, that would be taken for granted in other contexts, is not available (Goswami, 2008). And without an internet connection, many of the other ICT affordances arguably lose their educative value in the interconnected digital world represented in the global and national policy texts. What emerges in the context highlighted above is not only a disjuncture between flow along the techno-scape and the finance-scape, but also along the ideo-scape, particularly in relation to the idea that ICT must be used to support education. The idea of integrating ICT in teaching English is actually welcome in national and local institutional contexts, but insufficient technology hampers the implementation of the idea. As a consequence, the achievement of a globalising idea - which is that ICT must be used to support learning and teaching - is often not realised in practice at the local level in the context of pre-service EFL teacher education.

Information and communication technology is arguably crucial in English language teaching. As often recognised there are many benefits in applying technology in English language teaching [21], [22], [23]. For example, contend that globalisation has provided new challenges because technology has changed traditional practices for English teaching, which provides various technology-based alternatives, making both teaching and learning much more interesting and productive [5], [6]. Patel identified the benefits arising from the use of multimedia technology in learning and teaching to include: improvements in learning communication skills, student motivation, student understanding of western culture, teacherstudent interaction, support for context-relevant learning, and the capacity to facilitate malleable adjustments to the teaching material. But despite the clear mandate for the use of ICT in education at all levels, and research identifying the value of ICT to learning and teaching, the use of ICT remains an idea that in many instances is not put into practice in pre-service EFL teacher training or in field experience in Indonesian schools [25], [26], [27]. For example:

(2) For villagers, there are a lot of challenges, like... vocabulary, furthermore technology and media used. In villages we can use meaningful [teaching] instruments, but limited internet, limited communication and electronic media as well, which is influential, because in village schools, sometimes it is unaffordable to buy the tools and that affects the teaching of English...(Smith) 
The above excerpt highlights the impact of insufficient infrastructure on effectively teaching English, as mandated by Teacher Law No. 14/2005 [18], [19], particularly with an emphasis upon the use of ICT in education for the purpose of improving Indonesia's human capital for national development.

\section{Conclusion}

Based While the EFA agenda of improved educational quality is quite explicit, there are still issues of difference and disjuncture at the levels of national and local institutional policy documents and at the level of practice. Enhancing the quality of education as advised in EFA may still be problematic in practice. Even though the global message is supported through its articulation in national and institutional policies and there is some agreement between policies and practice ranging from the global and national to the institutional level, there are still some disjunctures in the use of ICT in teaching English..

The differences evident across policies and practice in the use of ICT in teaching English indicate that the mandated messages from the global agenda have not been optimally achieved yet. ICT implementations is still problematic. Due to limited financial capacity, it is inevitable that inequity of educational access still occurs. This study contributes to understanding the gap between mandated messages and practice. The illustration of the issues among policy documents and practice provides a basis for finding ways of minimising the problems of development programs in Indonesia..

\section{References}

[1] Jalal, F., Samani, M., Chang, M. C., Stevenson, R., Ragatz, A. B., \& Negara, S. D. (2009). Teacher certification in Indonesia: A strategy for teacher quality improvement. Jakarta, Indonesia: Departemen Pendidikan Nasional Republik Indonesia.

[2] Raihani. (2014). Creating multicultural citizents: A portrayal of contemporary Indonesian education. Oxford, UK: Routledge.

[3] Mulyasa. (2013). Pengembangan dan implementasi kurikulum 2013. Bandung, Indonesia: Remaja Rosdakarya.

[4] Buckworth, J. (2016 under examination). System failure? A phenomenological study of risk in pre-service teachers' in-school experience. Thesis submitted in fulfillment of the requirements for the Doctor of Philosophy. Darwin: Charles Darwin University.

[5] Patel, C. (2013). Use of multimedia technology in teaching and learning communication skill: An analysis. International Journal of Advancements in Research \& Technology, 2(7), 116-123. Retrieved from http://www.ijoart.org/docs/Use-ofMultimedia-Technology-in-Teaching-and- Learning-communication-skill.pdf

[6] Pun, M. (2013). The use of multimedia technology in English language teaching: A global perspective. Crossing the Border: International Journal of Interdisciplinary Studies, 1(1), 29-38. Retrieved from http://www.nepjol.info/index.php/CTBIJIS/article/viewFile/10466/8517

[7] Al-Zahrani, A. (2015). The place of technology integration in Saudi pre- service teacher education: Matching policy with practice. The Turkish Online Journal of Educational Technology 14(1), 151-163. Retrieved from 
http://ezproxy.cdu.edu.au/login?url=http://search.ebscohost.com/login.asp $\mathrm{x}$ ?direct=true \&AuthType $=\mathrm{ip}$,uid $\& \mathrm{db}=$ ehh $\& \mathrm{AN}=100258498 \&$ site $=$ ehost-live

[8] Merç, A. (2015). Using technology in the classroom: A study with Turkish preservice EFL teachers. The Turkish Online Journal of Educational Technology 14(2), 229- 240. Retrieved from

http://web.a.ebscohost.com.ezproxy.cdu.edu.au/ehost/pdfviewer/pdfviewer ?vid=3\&sid=bfede470-1fb6-4689-846bd03290781c14\% 40sessionmgr4006\&hid=4106

[9] Black, P., \& Goebel, Z. (2004). Nobody's a native speaker of everything: Teaching language variety and Indonesian code choice. Kajian Sastra: Jurnal Bidang Kebahasaan, Kesusastraan dan Kebudayaan, 28(1), 1-12. Retrieved from http://espace.cdu.edu.au/eserv/cdu:42531/Black_42531.pdf

[10] Motschnig-Pitrik, R., \& Holzinger, A. (2002). Student-centered teaching meets new media: Concept and case study. Educational Technology \& Society, 5(4), 160-172. Retrieved from http://www.ifets.info/journals/5_4/renate.html

[11] Durham, M. G., \& Kellner, D. M. (Eds.). (2006). Media and cultural studies (revised ed.). Boston, MA: Blackwell.

[12] Appadurai, A. (1996). Modernity at large: Cultural dimensions of globalization (Vol. 1). Minneapolis, MN: University of Minnesota.

[13] Carspecken, P. F. (1996). Critical ethnography in educational research: A theoretical and practical guide. London, UK: Routledge.

[14] Madya, S. (2002). Developing standards for EFL in Indonesia as part of the EFL teaching reform. TEFLIN Journal, 13(2), 142-151. Retrieved from http://journal.teflin.org/index.php/journal/article/view/130/129

[15] Madya, S. (2007). Searching for an appropriate EFL curriculum design for the Indonesian pluralistic society. TEFLIN Journal, 18(2), 196-221. Retrieved from www.journal.teflin.org/index.php/journal/article/download/111/106

[16] Republik Indonesia. (2003). Undang-undang RI No 20, 2003 tentang Sistem Pendidikan Nasional. Retrieved from www.inherent-dikti.net/files/sisdiknas

[17] Republik Indonesia. (2005). Peraturan pemerintah no 19 tahun 2005 tentang standar nasional pendidikan [Government decree no 19, 2005, on national standards for education]. Retrieved from http://www.unm.ac.id/files/surat/pp-19-tahun-2005-ttgsnp.pdf [18] Republik Indonesia. (2005). Undang-undang Republik Indonesia no 14 tahun 2005 tentang guru dan dosen. Retrieved from http://sindikker.ristekdikti.go.id/dok/UU/UUNo142005\%28Guru\%20\&\%20D osen $\% 29$.pdf

[18] Republik Indonesia. (2013). Peraturan pemerintah Republik Indonesia no 32 tahun 2013tentang perubahan atas peraturan pemerintah no 19 tahun 2005 tentang standar nasional pendidikan. Retrieved from http://sindikker.dikti.go.id/dok/PP/PP322013PerubahanPP19- 2005SNP.pdf

[19] UNESCO. (2000). The Dakar framework for action. Retrieved from unesdoc.unesco.org/images/0012/001211/121147e.pdf.

[20] Mishra, P., \& Koehler, M. J. (2006). Technological pedagogical content knowledge: A framework for teacher knowledge. Teachers College Record, 108(6), 1017.

[21]1UNESCO. (2004). Education for all: The quality imperative: EFA global monitoring report summary 2005. Retrieved from http://unesdoc.unesco.org/images/0013/001373/137333e.pdf 
[22] UNESCO. (2007). Education for all by 2015, Will we make it? Summary: EFA global monitoring report 2008. Retrieved from http://unesdoc.unesco.org/images/0015/001548/154820e.pdf

[23] Goswami, D. (2008). Wi-fi: The network fix. In R. Samarajiva \& A. Zainudeen (Eds.) ICT infrastructure in emerging Asia: Policy and regulatory roadblocks (pp. 131-156). New Delhi, India: SAGE \& InternationalnDevelopment Research Centre.

[24] Heyman, J. M., \& Campbell, H. (2009). The anthropology of global flows: A critical reading of Appadurai's 'disjuncture and difference in the global cultural economy'. Anthropological Theory, 9(2), 131-148. Retrieved from http://ant.sagepub.com.ezproxy.cdu.edu.au/content/9/2/131.full.pdf+html

[25] Harmer, J. (2007). The practice of English language teaching (4 ed.). Harlow, UK: Pearson.

[26] Prayitno, H.arun Joko, et all. "Directive Politeness Act Strategy in The Discourse of Education Column in National Newspaper as The Formation Of Students' Character in Indonesia". Humanities \& Social Sciences Reviews, Vol 7, No 2, 2019, pp 349-

[27] Leng, Yap Kwee \& Nor Aishah Buang. "The Involvement In Tunas Niaga Activities and The Entrepreneurial Attitude Among Secondary Schools". IJOLAE Indonesian Journal on Learning and Advanced Education. Vol.1, No.1, pp 15-25, 2019. 